\title{
Pillar Cell
}

National Cancer Institute

\section{Source}

National Cancer Institute. Pillar Cell. NCI Thesaurus. Code C33322.

A flattened cell that rests on the tympanic lip of the spiral lamina (inner pillar cell) and on the basilar membrane (outer pillar cell), thereby forming the tunnel of the Organ of Corti. 